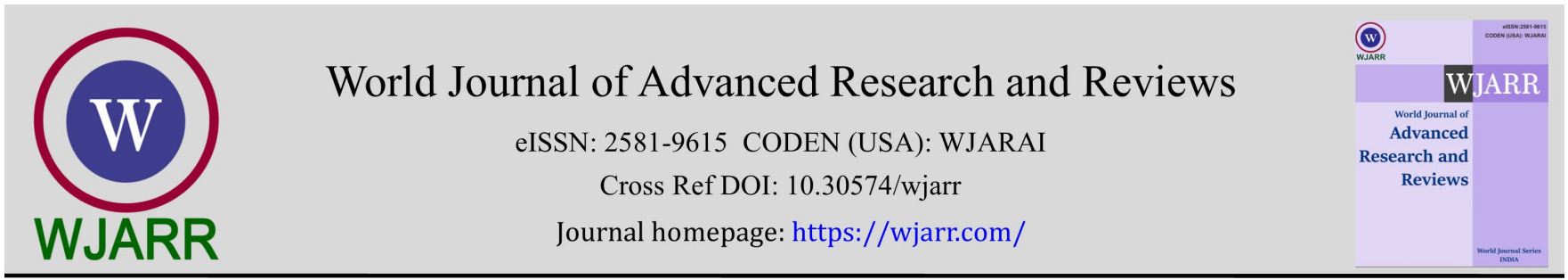

(RESEARCH ARTICLE)

\title{
Adaptation of plants derived from cultivated yam of Dioscorea cayenensis-D. rotundata complex species seeds germination in two agroecological zones of Benin
}

\author{
Assaba Idossou Elie 1, ${ }^{*}$, Yolou Mounirou 1, Bello Saliou 3, Babalakoun Adonis 1, Tiama Djakaridja 2 and \\ Zoundjihekpon Jeanne ${ }^{1}$ \\ ${ }^{1}$ Laboratory of Ecological Genetics, Department of Genetics and Biotechnologies, Faculty of Science and Technology, \\ University of Abomey-Calavi, (LGE/FAST/UAC), BP 4521 Cotonou, Republic of Benin. \\ 2 Biosciences Laboratory, Genetics and Plant Improvement Team, UFR / SVT, Joseph KI ZERBO University, Ouagadougou, \\ Burkina Faso. \\ ${ }^{3}$ Agricultural Research Center of South-Benin, National Agricultural Research Institute of Benin (CRA-Sud/INRAB).
}

World Journal of Advanced Research and Reviews, 2021, 09(03), 027-041

Publication history: Received on 06 January 2021; revised on 15 February 2021; accepted on 17 February 2021

Article DOI: https://doi.org/10.30574/wjarr.2021.9.3.0019

\begin{abstract}
Vegetative propagation of plants promotes the accumulation of viruses in plant material; this causes the loss of vigor and consequently the drop of vegetable yield. Keep up productivity level of vegetatively propagated plants; it is therefore important to regenerate genetic material by sexual reproduction to improve the biodiversity. The main objective of this study is to improve yam seeds by sexual way, specifically to assess the response of seedlings from yam seeds in two agroecological areas, area IV (Djougou), in Sudanese climate and area V (Bantè), in transition climate. Seedling were transplanted in this agroecological areas using a completely Randomized design with three replications. Data was analyzed using one way ANOVA at 5\% level of significance and a mean comparison test. Seedling survival rate is significantly different, $55.41 \%$ in zone IV and $23.60 \%$ in zone $\mathrm{V}$, but the rate of tuberization of the two areas is similar, $55.63 \%$; of zone IV and 57.62\%; of zone V. The average of the tubers length and their weight are respectively $13.21 \mathrm{~cm}$ and $24.87 \pm 19.22 \mathrm{~g}$ in zone IV and $8.95 \mathrm{~cm}$ and $10.30 \pm 9.91 \mathrm{~g}$ in zone V. This results show that microtubers produced from the seeds show a high degree of heterogeneity, and, varieties creation and improvement is possible from the seeds. This technique would promote the selection of varieties adapted to current climatic conditions.
\end{abstract}

Keywords: Yam seed; Germination; Agroecological zone; Microtuber; Selection

\section{Introduction}

Yam's place in the tropical zone is justified by the climatic and edaphic conditions. Climatic variation in general and especially drought have negative impacts on several components, which condition success of agricultural production in general, and mainly of yam [1, 2, 3, 4], occasion loss of yam's diversity and yields drop. Moreover, degradation of soil fertility which occasion around $3 \%$ of drop of yield in the world [5], thus affecting food self-sufficiency [6, 7]

However, the quality of the seed favors the adaptation of plants to these new conditions. For food security and sovereignty, it is therefore urgent to compensate diversity loss and yield decrease-installing varieties adapted to different climatic and soil conditions.

\footnotetext{
* Corresponding author: Assaba Idossou Elie; Phone: (+229)96162064; Email: assaba.e@gmail.com

Laboratory of Ecological Genetics, Department of Genetics and Biotechnologies, Faculty of Science and Technology, University of Abomey-Calavi, (LGE/FAST/UAC), BP 4521 Cotonou, Republic of Benin. 
Preserve food security and sovereignty, need to have good quality of seed, which depend plants adaptation of environment variation. Sexual way can carry out these kinds of seed. Yams of the Dioscorea cayenensis-D. rotundata species complex produce fruit and seeds, able to sprout after sowing [8, 9, 10,11,12,13]. In North of Benin [14], in North of Côte d'Ivoire [15] and in center of Benin [16], this authors shown that in each yam's field around 4.800 to 27.000 seeds is yield in average each year.

Farmer integrated tuber of seedling from seed germination in nature in their cultivated gene pool unconsciously [17, $18,19]$. Moreover, studies of germination of yam seeds from farmer's field have shown germination rates ranging from 30 to $80 \%[8,11,20,21]$. Improve genetic diversity of the yam by sexual reproduction require to observe the behavior of the seedlings resulting of yam's seeds germination. This study aims to assess the response of seedlings produced from yam seeds in two agroecological zones of Benin.

\section{Material and methodology}

\subsection{Material}

Vegetal material is seedlings resulting from the germination of seeds collected from ten (10) cultivated yam, in the fields of farmers in three (03) Municipalities of Benin (Table 1).

Table 1 Characteristics and origins of the female parents of the seeds collected.

\begin{tabular}{|l|l|l|l|}
\hline Name & Cycles & Villages & Municipalities \\
\hline Dodo A & Late & Agoua & Bantè \\
\hline Katala & Intermediate & Agoua & Bantè \\
\hline Mafobo & precocious & Agoua & Bantè \\
\hline Ewourou & Intermediate & Agoua & Bantè \\
\hline Agatou & Intermediate & Agoua & Bantè \\
\hline Gnidou & Intermediate & Adjiro & Bassila \\
\hline Dodo I & Late & Idaho & Dassa \\
\hline Kpakala & Late & Idaho & Dassa \\
\hline Adigbili & Precocious & Idaho & Dassa \\
\hline Moroko & precocious & Soclogbo & Dassa \\
\hline
\end{tabular}

\subsection{Methodology}

\subsubsection{Study environment}

The seeds germination was implement on the experimental site of the Department of Genetics and Biotechnologies of the University of Abomey-Calavi, located in the agro-ecological zone VI (Nitisols land area), at $15 \mathrm{~km}$ in north of Cotonou $\left(6^{\circ} 30^{\prime} \mathrm{N}\right.$ and $\left.2^{\circ} 24^{\prime} \mathrm{E}\right)$. Its climate is of the subequatorial type with a bimodal rainfall regime. The mean annual precipitation is $1,168.3 \mathrm{~mm}$ and the mean annual temperature is around $27.75{ }^{\circ} \mathrm{C}$, with an amplitude of $4{ }^{\circ} \mathrm{C}$. Temperature extremes are recorded in March for the high and in August for the weak [22].

The seedlings from yam's seeds were transplanted into two (2) agro-ecological zones; agro-ecological zones IV and V described by the National Action Program for Adaptation to Climate Change of Benin [23] as zones offering propice climatic conditions of yams growing. The first site is located in Kpayerou in the Municipality of Djougou (agro-ecological zone IV, West-Atacora zone), with a Sudanese-type climate and the second in Agoua in the Municipality of Bantè (agroecological zone V, cotton zone of Center-Benin) with Sudano-Guinean climate (Figure 1, Figure 2). 


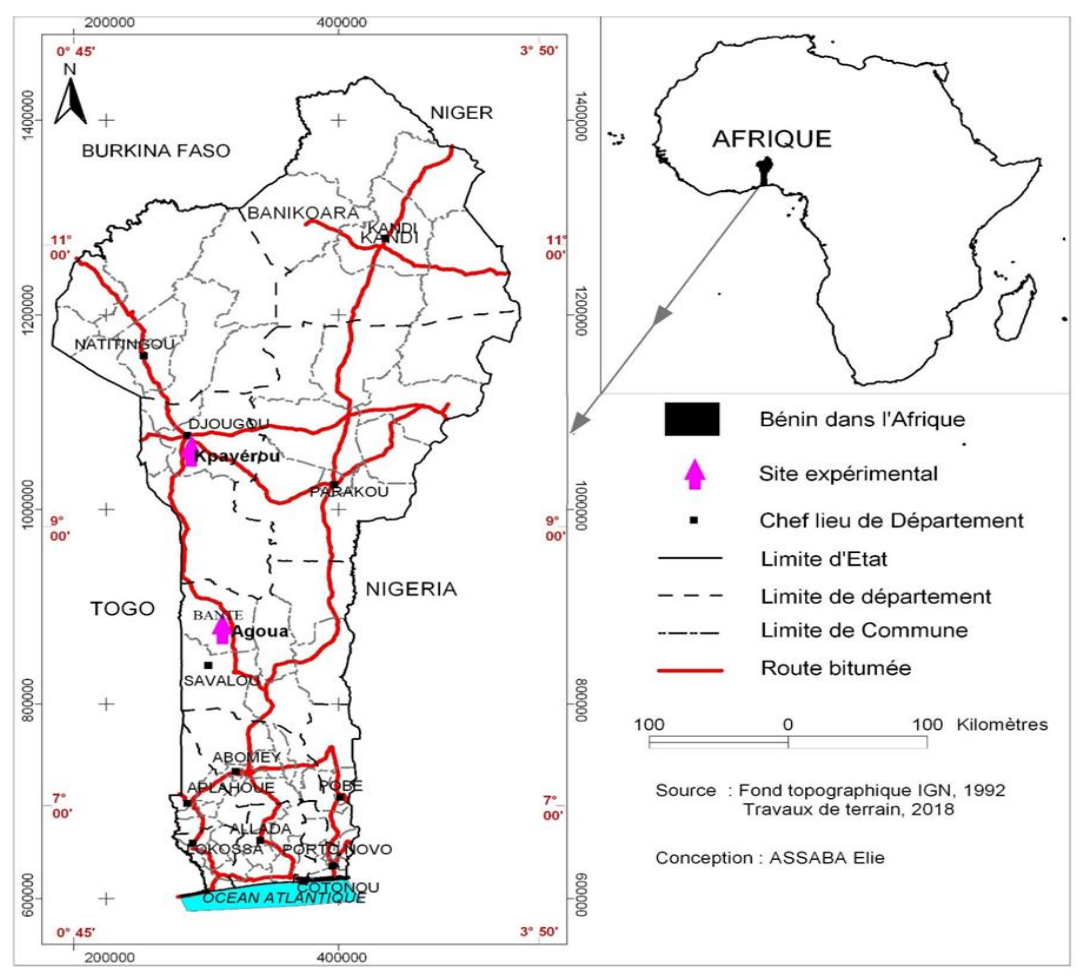

Figure 1 Map of republic of Benin in West Africa

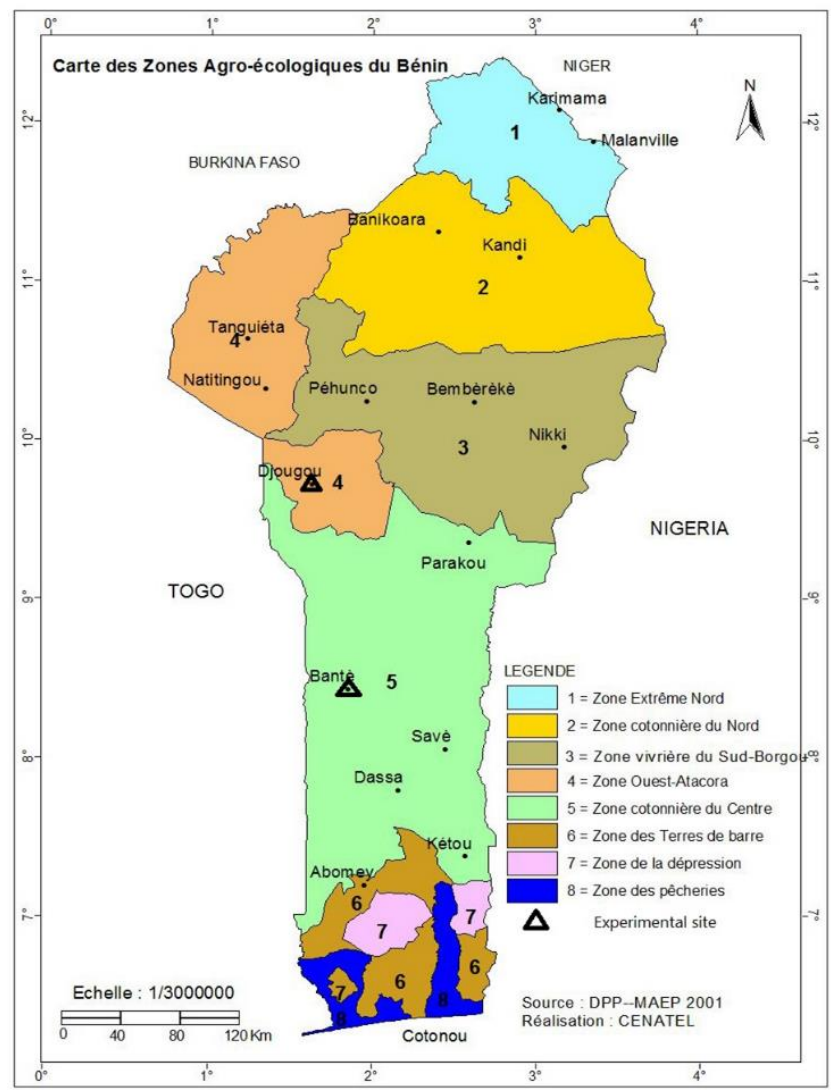

Figure 2 Map of Benin showing the two experimental sites in two different agroecological zones 


\subsection{Sampling of producers}

The farmer's selection criteria are based on their knowledge and expertise of yam cultivation, being voluntary and available to follow the seedlings in the field and access to the field.

\subsection{Seeds collection and transplantation}

The fruits collected in the farmers' fields in December 2015 were sundried for two weeks. After dry, the seeds were extracted and stored at room temperature. In February 2016, the seeds extracted from dry fruits were sown in tank of $50 \mathrm{~cm}$ long, $25 \mathrm{~cm}$ wide and $15 \mathrm{~cm}$ deep, filled with mould. In each tank, 30 seeds are sown, tanks are been order by a completely randomized design with three replications per cultivar [24], germinations are observed after two (02) weeks and this up to eight (08) weeks (Figure 3a).

Seedling are been transferred to tanks on pot (Figure 3b), and three weeks after, 582 seedlings were throwed to two producer's fields, respectively 265 seedlings in agro-ecological zone IV and 317 seedlings in agro-ecological zone V. In the two agro-ecological zones, the seedlings were transplanted in a completely randomized design with three replications per cultivar.

Each block is made up of 10 rows of mounds, and each row is made up of ten mounds (agro-ecological zone IV) or a tenhole ridge (agro-ecological zone V) according to the cultivation techniques adapted to each agro-ecological zone and the know-how of concerned Farmers. The spacing between the rows is $80 \mathrm{~cm}$ and between the mounds or pockets are 60 $\mathrm{cm}$ apart. In each mound or pocket, a single seedling is transplanted there (Figure 2c). Cultivation in the different agroecological zones was carried out in July 2016.
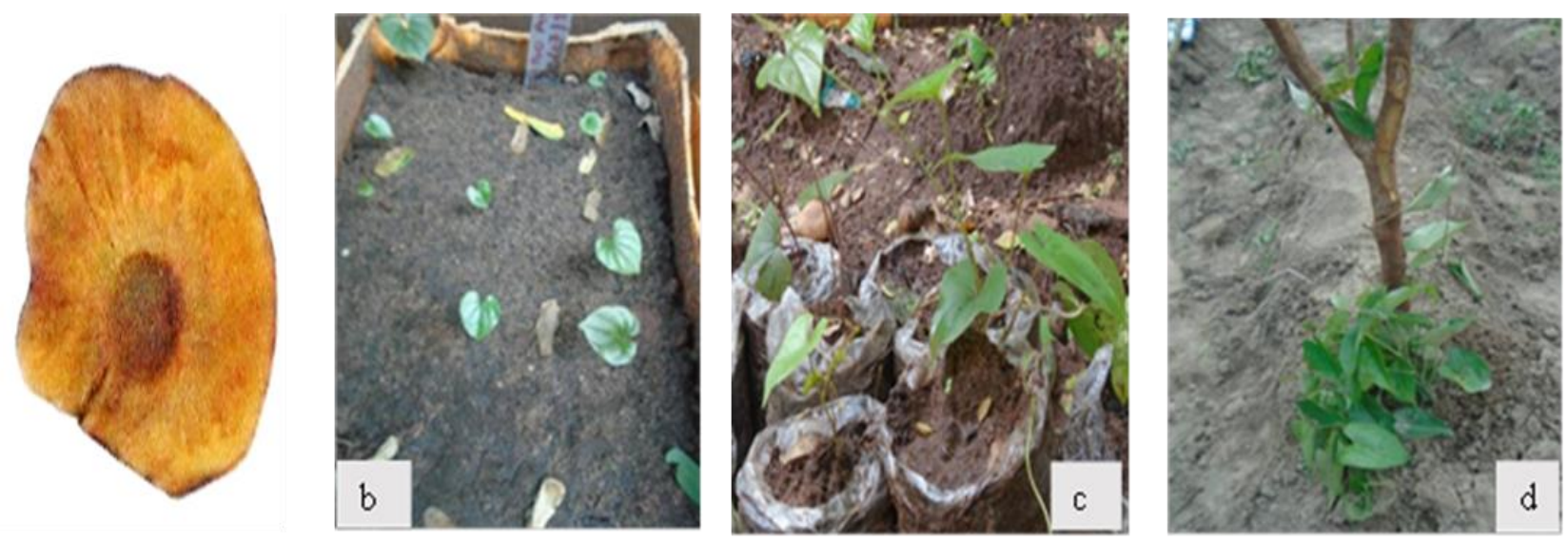

Figures 3a to 3d Different stages of yam development: (a) Yam seed, (b) yam seedlings at germination stage, (c) yam seedlings transplanted in pots, (d) yam seedling of two (02) months age after transplantation

\subsection{Data collection}

On each experimental site, two (02) months after transplantation, the number of survival seedlings was noted per cultivar (hybrid descendant), and the number of seedlings which have tuberized is determined.

At the end of the vegetative cycle, the tubers were harvested and ten morphological parameters were observed. These are three (03) quantitative parameters (weight, length and circumference) and seven (07) qualitative parameters (shape of the tuber, color of the skin of the tuber, appearance of the tuber, presence or not of rootlets on the tubers, location of the rootlets on the tubers, presence or not of stripes and presence or not of ramified on the tubers).

\subsection{Data analysis}

The survival or recovery rate which is the ratio of the number of seedling which having complete their vegetative cycle by the total seedling transplanted was calculated, and the rate of tuberization which is the ratio between the number of seedlings having given a tuber and the total number of seedlings having completed their vegetative cycle. The variation in the rate of recovery and tuberization were subjected to an analysis of variance (ANOVA) according to the Generalized Linear Model (GLM) in fishtail. The quantitative parameters that follow normality were subjected to an ANOVA and the Kruskal Wallis test for those, which do not flow normality. To perform the Pearson correlation test, the shape of the 
tuber, the color of its skin, the presence or absence of rootlets and stripes on the tuber were been coded according to the yam descriptor standard [25].

\section{Results}

\subsection{Seedling recovery rate}

In agro-ecological zone IV, survival rate is between $42.55 \%$ and $77.5 \%$ respectively in the seedling having as female parents the cultivars Dodo I and Gnidou, with an average of $57.72 \%$. The best survival rates were observed in the descendants of female cultivars Gnidou, Katala, Mafobo and Agatou with respective rates of $77.5 \%, 74.07 \%, 63.63 \%$ and $62.5 \%$ (Figure 3). A highly significant difference was observed between survival rate of the different accessions at the $5 \%$ threshold with a probability $(\mathrm{P}=0.036)$ in this agro-ecological zone.

Of the 250 seedlings transplanted in agro-ecological zone $V$, the recovery rate varies from $12.5 \%$ to $40.74 \%$ respectively in seedling having as female parents the cultivars Moroko and Dodo A. The descendants of female cultivars Gnidou, and Kpakala yielded $34.61 \%$ and $31.03 \%$ respectively (Figure 4$)$. There is no significant difference $(P=0.079)$ between the recovery rates of the different hybrids in this agroecological zone.

The variation in the recovery rate in the two agro-ecological zones is very significantly difference at the $5 \%$ level, with an associated probability of $<0.0001$.

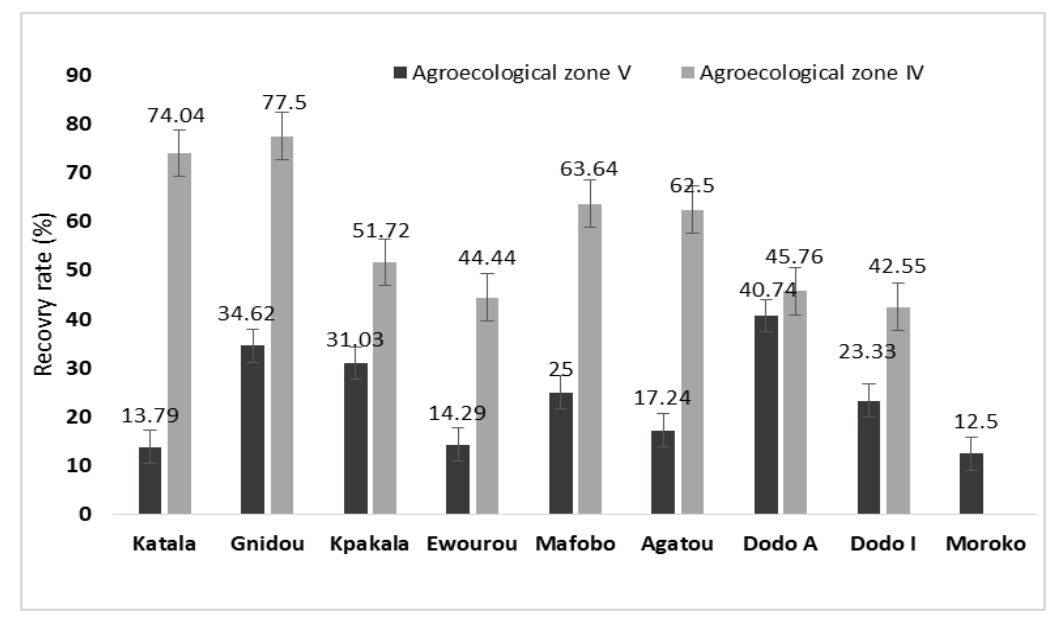

Figure 4 Seedling recovery rate (\%) in agroecological zones IV and V

\subsection{Tuberization rate}

Seedlings tuberization rate in the agro-ecological zone IV fluctuate $0 \%$ obtained in in the offspring of female parents Moroko and Mafobo to 85\% obtained in the cultivar Dodo I with an average rate of 55.41\%. The best performing hybrids in this area are those having as female parents the cultivars Dodo A with 59.26\%, Katala with $60 \%$, Ewourou with $75 \%$, and Dodo I with 85\% (Figure 5).

The tuberization rates in the agro-ecological zone $\mathrm{V}$ varied from $25 \%$ to $80 \%$ respectively observed in hybrids from cultivars Katala and Agatou with an average rate of $57.62 \%$. The best performing hybrids in this area are the descendants of cultivars Gnidou with 55.56\%, Dodo I with 57.14\%, Dodo A with 72\%, Kpakala with 77.78\% and Agatou with $80 \%$ (Figure 5).

The average rate of tuberization was $57.62 \%$ in agro-ecological zone $\mathrm{V}$ and $55.41 \%$ in agro-ecological zone IV. No significant difference $(\mathrm{P}=0.46)$ is observed between the average rates of tuberization in the two agro-ecological zones. 


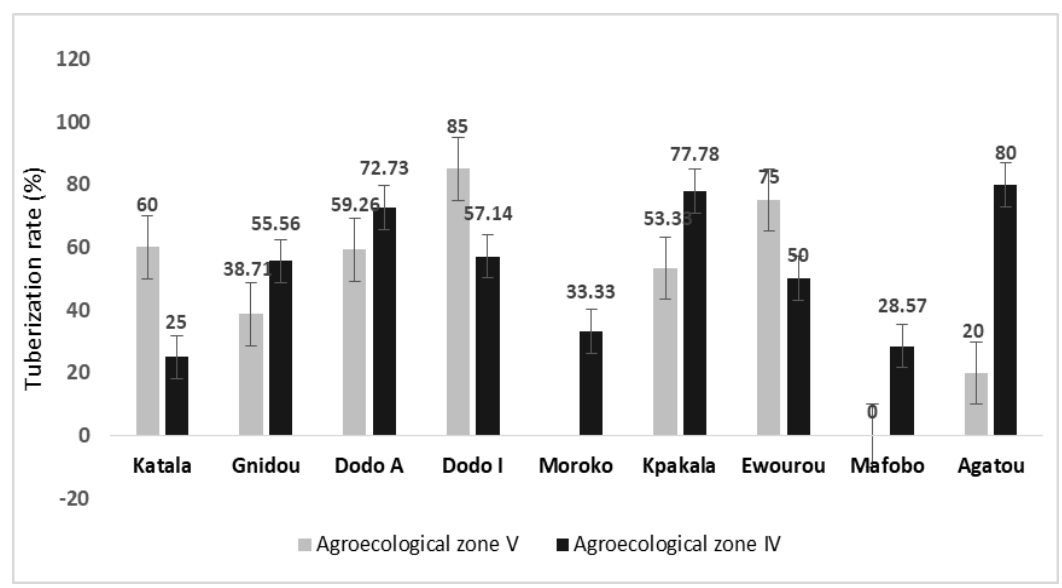

Figure 5 Tuberization rates (\%) of accessions in the two agro-ecological zones V and VI

The rate of tuberization of hybrids from the cultivar Katala in agro-ecological zone V (25\%) was lower than that of agroecological zone IV which was $60 \%$. The same observation was made for the genotype produced by the cultivar Agatou which had a tuberization rate of $20 \%$ in agro-ecological zone IV, against $80 \%$ in agro-ecological zone V.

\subsection{Agromorphological characteristics of the first generation tubers}

In the agro-ecological zone IV, the microtubers length varies between 2.4 and $30 \mathrm{~cm}$ respectively in the seedlings from the cultivars Katala and Kpakala, with an average length of $13.01 \pm 5.84 \mathrm{~cm}$ (Figure 6). The probability associated to the means of this variable $(\mathrm{P}=0.13)$ not reveal any significant difference between accessions of this area.

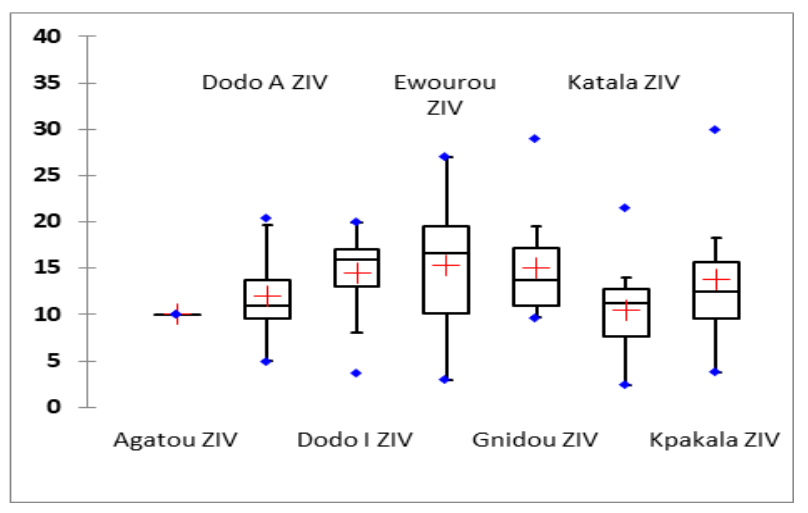

Figure 6 Length $(\mathrm{cm})$ of the first generation tubers of accessions in the agrecological zone IV

The length of the first generation tubers of the agro-ecological zone $\mathrm{V}$ is between 1.5 and $32 \mathrm{~cm}$ observed respectively in the descendants of the cultivars Moroko and Mafobo, with an average of $8.95 \pm 7.4 \mathrm{~cm}$ (Figure 7). The difference of the microtubers length is not statistically significant $(P=0.44)$ at the $5 \%$ level.

In agro-ecological zone IV, the circumference of the microtubers varied from 2.5 to $10 \mathrm{~cm}$ respectively in the genotypes carried by the cultivars DodoA and Katala, with an average circumference of $5.93 \pm 1.38 \mathrm{~cm}$ (Figure 8). The probability linked to this mean $(\mathrm{P}=0.71)$ shows a similarity between the circumference of the first generation tubers in zone IV.

The first generation tubers circumference in the agro-ecological zone $\mathrm{V}$ is between $1.2 \mathrm{~cm}$ and $6.8 \mathrm{~cm}$ observed respectively in the descendants of cultivars Kpakala and Agatou, with an average of $4.34 \pm 0.88 \mathrm{~cm}$. The very low value of the standard deviation reflects a small variation between the circumference of the first generation tubers, and this is confirmed by the probability $\mathrm{P}=0.47$ associated with this mean (Figure 9). 
World Journal of Advanced Research and Reviews, 2021, XX(XX), XXX-XXX

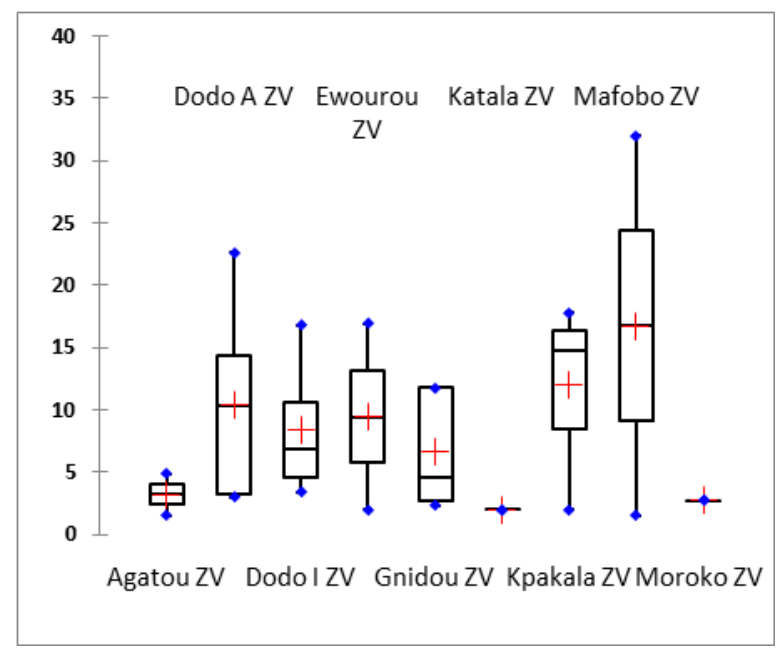

Figure 7 Length $(\mathrm{cm})$ of the first generation tubers of accessions in the agrecological zone $\mathrm{V}$

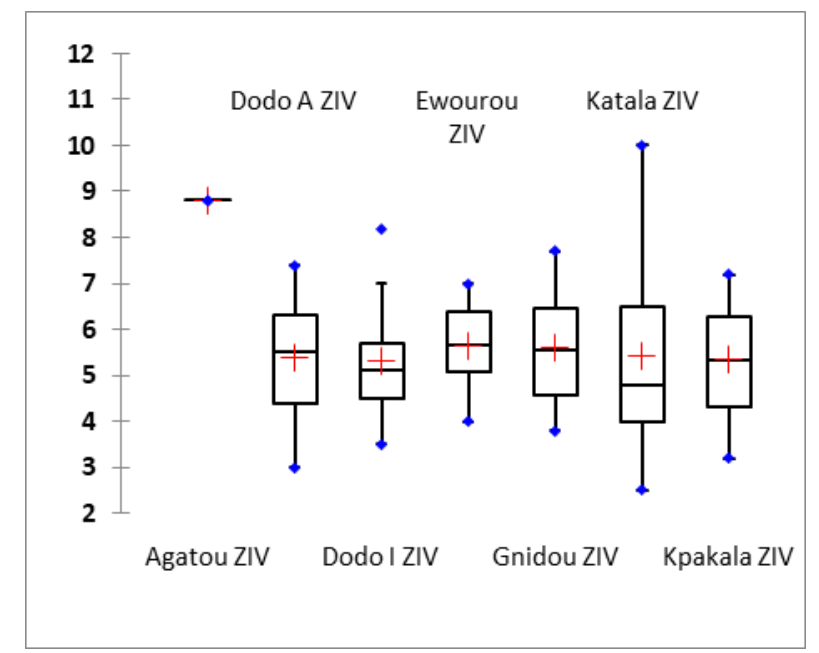

Figure 8 Circumference $(\mathrm{cm})$ of the tubers of accessions in the agroecological zone IV

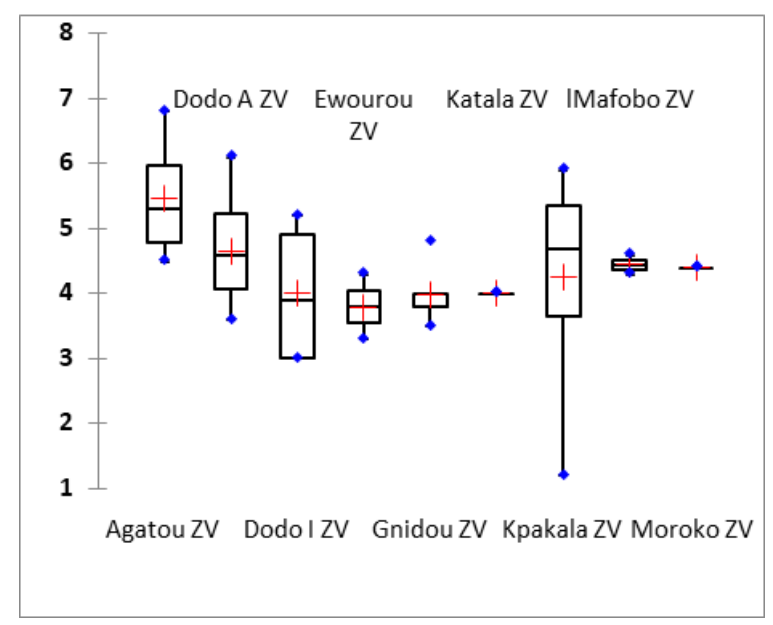

Figure 9 Circumference $(\mathrm{cm})$ of the tubers of accessions in the agrecological zone $\mathrm{V}$ 
The weight of the first generation tubers is between $3 \mathrm{~g}$ and $113 \mathrm{~g}$, respectively in the genotypes from cultivars Dodo I and Gnidou, with an average of $24.87 \pm 19.22 \mathrm{~g}$ in agro-ecological zone IV (Figure 10). The value of the standard deviation (19.22) shows variability of the different hybrid's microtubers weight, but not statistically difference $(\mathrm{P}=$ $0.219)$.

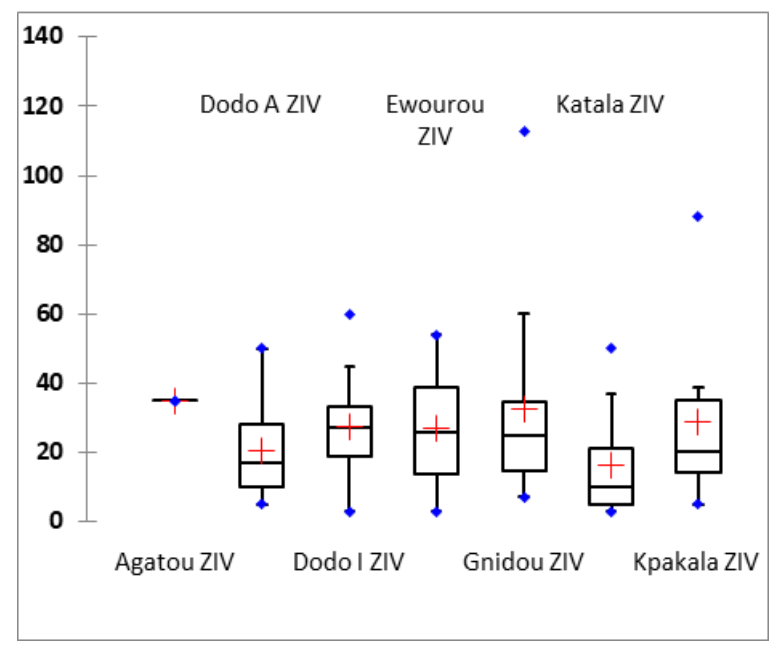

Figure 10 Weight (g) of the first generation tubers of accessions in agrecological zone IV

In agro-ecological zone $\mathrm{V}$, the weight of the microtubers obtained is between 2 and $37 \mathrm{~g}$, observed in the hybrids carried by cultivars Gnidou, Ewourou, Katala and Kpakala and Mafobo with an average of $10.30 \pm 9.91 \mathrm{~g}$ (Figure 11). The probability associated with this comparison of mean $(\mathrm{P}=0.439)$ does not reveal a significant difference in microtubers weight between cultivars.

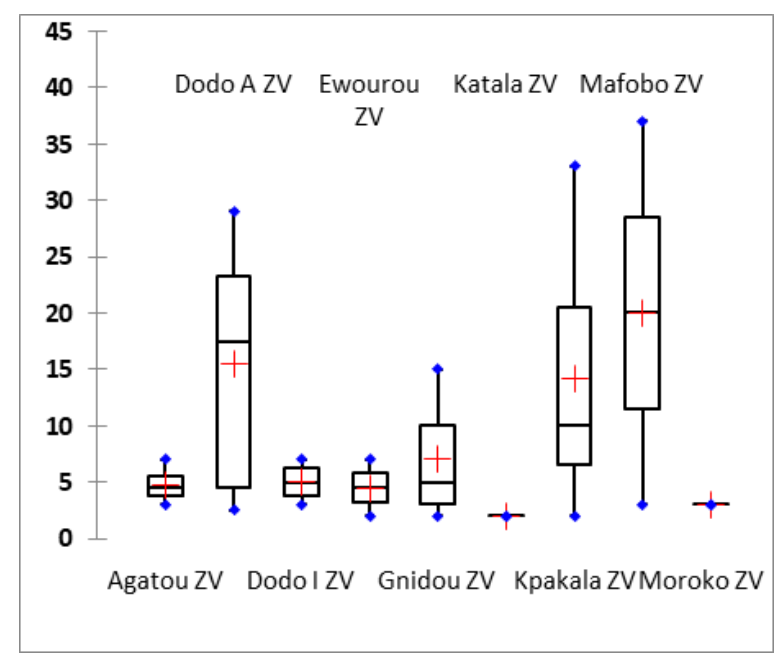

Figure 11 Weights (g) of the first generation tubers of accessions in agrecological zone $\mathrm{V}$

The means comparison test revealed a very highly significant difference between the length of the tubers obtained of the two agro-ecological zones with $\mathrm{P}=0.0007$ (Figure 12).

The probability associated of means comparison test $(\mathrm{P}=0.0003)$, revealed a very highly significant difference between the circumference of the first generation tubers of the two agro-ecological zones (Figure 12).

The probability associated with the comparison of the means $(\mathrm{P}<0.0001)$, revealed a very highly significant difference between the mean weight of the microtubers obtained in the two agro-ecological zones (Figure 12). 
World Journal of Advanced Research and Reviews, 2021, XX(XX), XXX-XXX

Table 2 Relative importance (\%) of the first generation tubers of accessions for morphological descriptors.

\begin{tabular}{|c|c|c|c|c|c|c|c|c|c|c|c|c|c|c|c|c|c|}
\hline \multirow{2}{*}{$\begin{array}{l}\text { Agroeco- } \\
\text { logical } \\
\text { zones }\end{array}$} & \multirow{2}{*}{ Name } & \multicolumn{2}{|c|}{ Shape of tuber } & \multicolumn{2}{|c|}{$\begin{array}{l}\text { Color of tuber } \\
\text { skin }\end{array}$} & \multicolumn{2}{|c|}{$\begin{array}{l}\text { Tuber } \\
\text { appearance }\end{array}$} & \multirow[t]{2}{*}{$\begin{array}{l}\text { Absence } \\
\text { of } \\
\text { rootlets } \\
\text { on } \\
\text { tubers }\end{array}$} & \multicolumn{3}{|c|}{$\begin{array}{l}\text { Location of the rootlets } \\
\text { on tubers }\end{array}$} & \multicolumn{3}{|l|}{ Stripe } & \multicolumn{3}{|c|}{ Digited } \\
\hline & & Oval & $\begin{array}{l}\text { Cylin- } \\
\text { dric }\end{array}$ & $\begin{array}{l}\text { Purple } \\
\text { clair }\end{array}$ & Purple & $\begin{array}{l}\text { smooth } \\
\text { skin }\end{array}$ & Rough & & $\begin{array}{l}\text { Top of } \\
\text { tuber }\end{array}$ & $\begin{array}{l}\text { Base } \\
\text { of the } \\
\text { tuber }\end{array}$ & $\begin{array}{l}\text { Whole } \\
\text { tuber }\end{array}$ & Absent & Top & $\begin{array}{l}\text { Whole } \\
\text { tuber }\end{array}$ & Absent & Middle & Base \\
\hline \multirow{7}{*}{ IV } & Dodo I & 0 & 100 & 45,45 & 54,54 & 13,63 & 86,37 & 77,27 & 9,09 & 0 & 13,63 & 0 & 4,54 & 95,45 & 100 & 0 & 0 \\
\hline & Dodo A & 14,28 & 85,92 & 35,91 & 64,29 & 64,29 & 35,91 & 85,92 & 7,14 & 0 & 7,14 & 85,92 & 14,28 & 0 & 100 & 0 & 0 \\
\hline & Ewourou & 20 & 80 & 20 & 80 & 60 & 40 & 60 & 40 & 0 & 0 & 100 & 0 & 0 & 100 & 0 & 0 \\
\hline & Katala & 28,57 & 71,43 & 42,86 & 57,14 & 64,29 & 35,91 & 78,57 & 0 & 0 & 27,27 & 0 & 0 & 100 & 100 & 0 & 0 \\
\hline & Kpakala & 30 & 70 & 10 & 90 & 70 & 30 & 80 & 20 & 0 & 0 & 0 & 30 & 70 & 90 & 0 & 10 \\
\hline & Gnidou & 0 & 100 & 81,80 & 18,20 & 100 & 0 & 54,55 & 0 & 18,17 & 27,28 & 100 & 0 & 0 & 100 & 0 & 0 \\
\hline & Agatou & 100 & 0 & 0 & 100 & 0 & 100 & 100 & 0 & 0 & 0 & 100 & 0 & 0 & 100 & 0 & 0 \\
\hline \multicolumn{2}{|c|}{ Great mean } & 27,55 & 72,48 & 33,72 & 66,31 & 53,17 & 46,88 & 76,62 & 10,89 & 2,60 & 10,76 & 55,13 & 6,97 & 37,92 & 98,57 & 0,00 & 1,43 \\
\hline \multirow{7}{*}{ V } & Kpakala & 14,29 & 85,71 & 0 & 100 & 57,15 & 42,85 & 0 & 42,85 & 0 & 57,15 & 57,15 & 0 & 42,85 & 100 & 0 & 0 \\
\hline & Gnidou & 60 & 40 & 60 & 40 & 40 & 60 & 0 & 20 & 0 & 80 & 100 & 0 & 0 & 100 & 0 & 0 \\
\hline & Dodo A & 44,44 & 55,55 & 0 & 100 & 66,67 & 33,33 & 11,11 & 33,33 & 0 & 55,56 & 0 & 11,11 & 88,89 & 100 & 0 & 0 \\
\hline & Mafabo & 50 & 50 & 100 & 0 & 0 & 100 & 0 & 50 & 0 & 50 & 50 & 50 & 0 & 100 & 0 & 0 \\
\hline & Dodo I & 60 & 40 & 20 & 80 & 20 & 80 & 0 & 40 & 0 & 60 & 60 & 0 & 40 & 100 & 0 & 0 \\
\hline & Ewourou & 50 & 50 & 100 & 0 & 100 & 0 & 0 & 50 & 50 & 0 & 0 & 50 & 50 & 100 & 0 & 0 \\
\hline & Agatou & 100 & 0 & 75 & 25 & 25 & 75 & 0 & 50 & 0 & 50 & 100 & 0 & 0 & 100 & 0 & 0 \\
\hline \multicolumn{2}{|c|}{ Great mean } & 54,10 & 45,89 & 50,71 & 49,29 & 44,12 & 55,88 & 1,59 & 40,88 & 7,14 & 50,39 & 52,45 & 15,87 & 31,68 & 100,00 & 0,00 & 0,00 \\
\hline
\end{tabular}




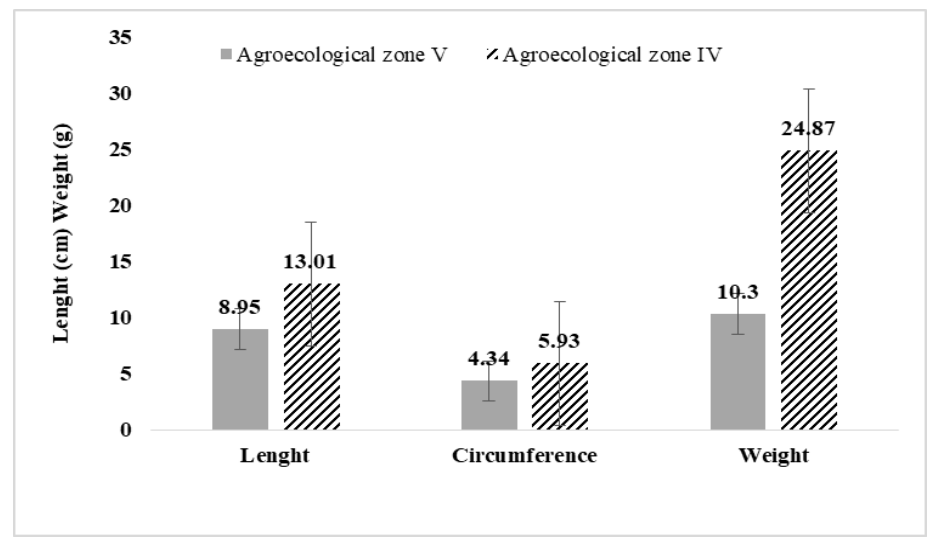

Figure 12 Means of length $(\mathrm{cm})$, circumference $(\mathrm{cm})$ and weight $(\mathrm{g})$ of first generation tubers by agroecological zone

In agroecological zone IV, $72 \%$ of the first generation tubers were cylindrical, $66.31 \%$ had purple skin color and $53.17 \%$ had smooth skin. The rootlessness was found on $76.62 \%$ of these tubers which are all (100\%) scratch-free, with $1.43 \%$ branching observed in the first generation tubers of Kpakala seedlings (Table 2).

In agroecological zone $\mathrm{V}$, the first generation tubers were oval (54.10\%), light purple (50.71\%) and rough (55.88\%) in color. The $98.41 \%$ of these tubers had roots, either over their entire surface or at the top; stripes were observed on $52.45 \%$ of the tubers and all of them (100\%) unbranched (Table 2).

Pearson's correlation shows that the presence or absence of roots is positively correlated with agroecological zones ( $\mathrm{r}$ $=0.96)$. In the two agro-ecological zones, morphological heterogeneity of the first generation tubers was observed within each cultivar seedling and between all cultivars of seedlings (Figures 13a, 13b, 14a, 14b, 15a, 15b, 16, 17, 18 and 19).

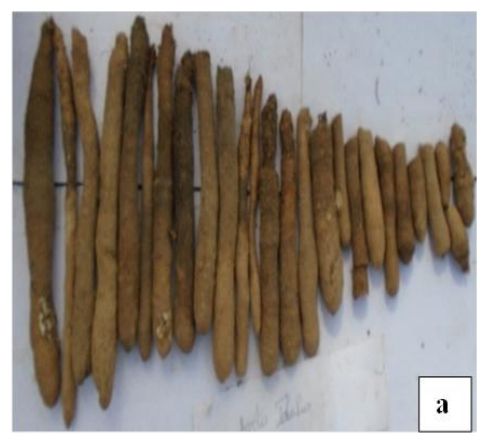

Figure 13a First generation tubers obtained from seedlings of the accession Dodo in agroecological zone IV

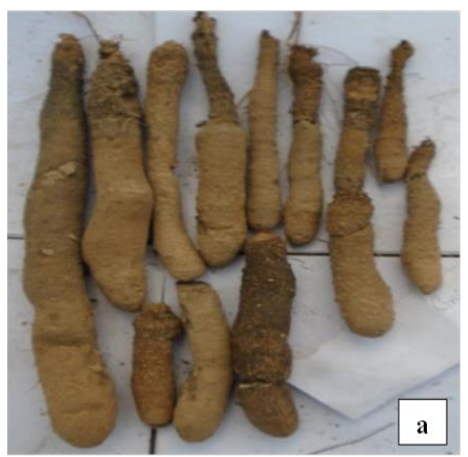

Figure 14a First generation tubers obtained from seedlings of the accession Gnidou in agroecological zone IV

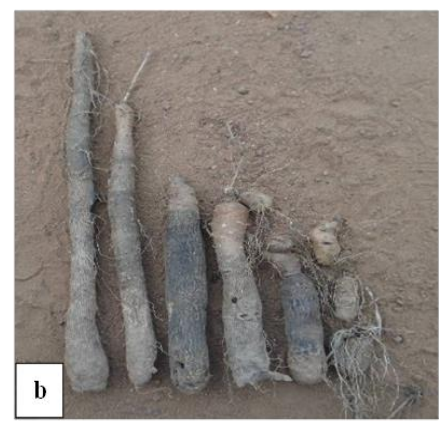

Figure 13b First generation tubers obtained from seedlings of the accession Dodo in agroecological zone $\mathrm{V}$

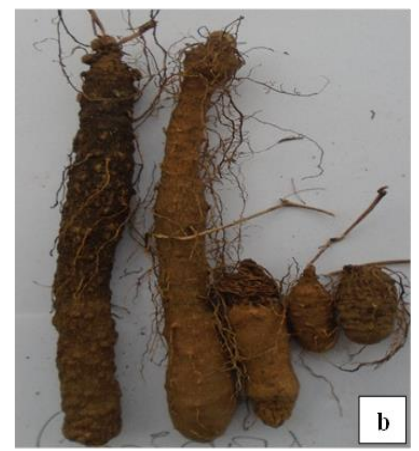

Figure 14b First generation tubers obtained from seedlings of the accession Gnidou in agroecological zone $\mathrm{V}$ 


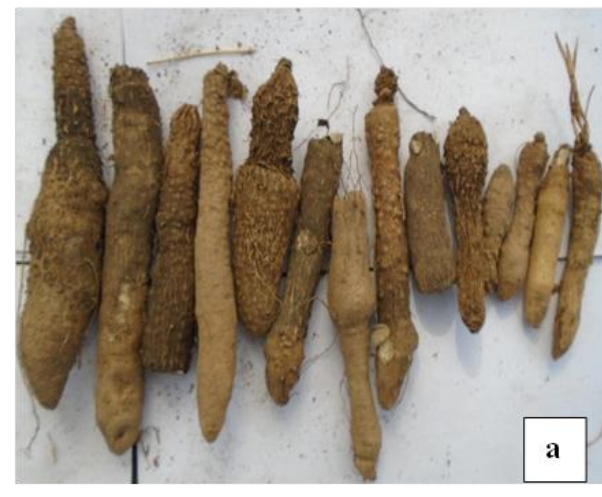

Figure 15a First generation tubers obtained from seedlings of the accession Katala in agroecological zone IV

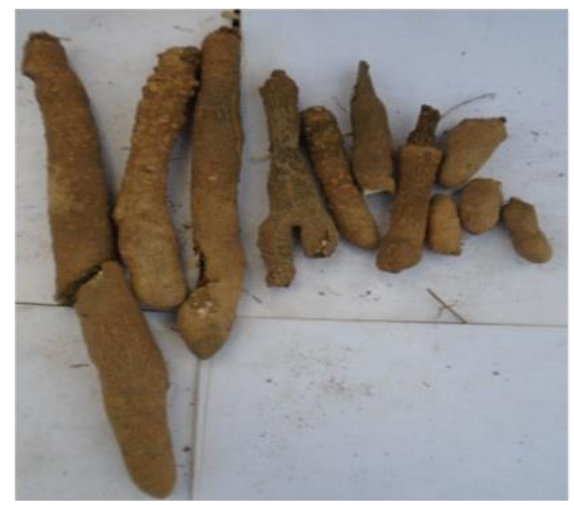

Figure 16 First generation tubers obtained from seedlings of the accession Kpakala in agroecological zone IV

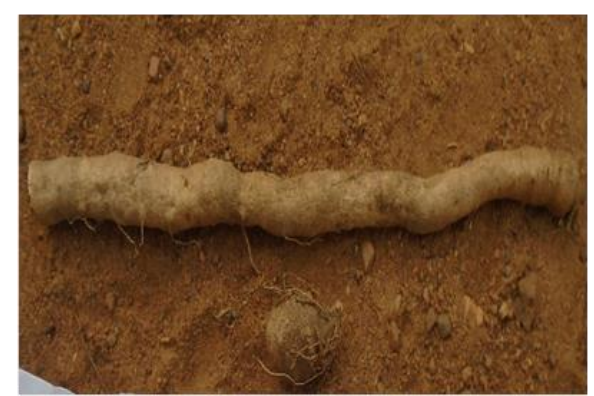

Figure 18 First generation tubers obtained from seedlings of the accession Ewourou in agroecological zone $\mathrm{V}$

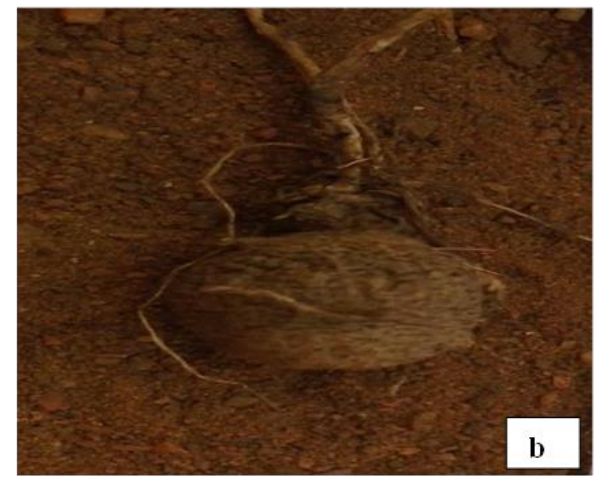

Figure 15b First generation tubers obtained from seedlings of the accession Katala in agroecological zone $\mathrm{V}$

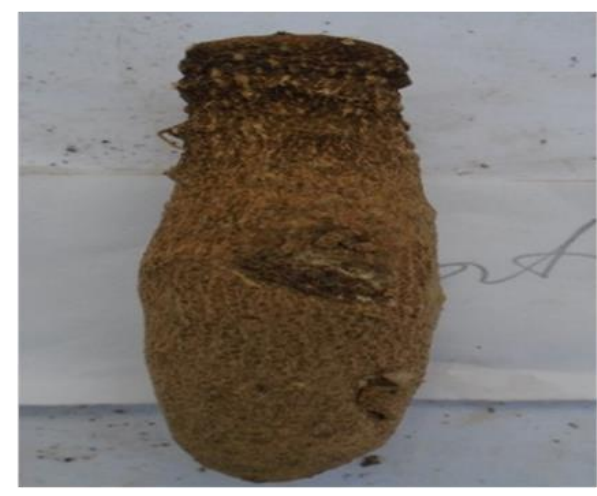

Figure 17 First generation tubers obtained from seedlings of the accession Agatou in agroecological zone IV

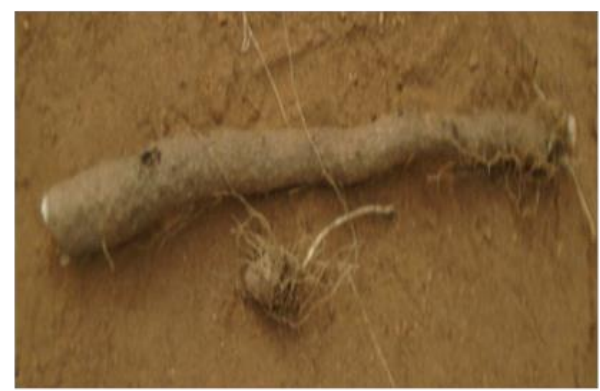

Figure 19 First generation tubers obtained from seedlings of the accession Mafobo in agroecological zone $\mathrm{V}$

\subsection{Correlation between agro-morphological parameters}

The weight of the tubers is positively correlated with their circumference $(r=0.58)$ and their length $(r=0.80)$. Tuber shape is negatively correlated with length $(r=-0.59)$ and weight $(r=-0.38)$. The presence of stripes on a tuber is correlated by its color $(r=0.40)$. The more strongly colored was the tuber; more the stripe appeared on the colored part (Table 3). 
Table 3 Correlation between the agro-morphological parameters of tubers

\begin{tabular}{|l|l|l|l|l|l|l|l|}
\hline Variables & $\begin{array}{l}\text { Lenght } \\
\mathbf{( c m )}\end{array}$ & $\begin{array}{l}\text { Circumfe } \\
\text { rence(cm) }\end{array}$ & $\begin{array}{l}\text { Weight } \\
\mathbf{( g )}\end{array}$ & Shape & $\begin{array}{l}\text { Tuber } \\
\text { skin } \\
\text { color }\end{array}$ & Rootlet & Stripe \\
\hline Lenght (cm) & 1 & & & & & & \\
\hline $\begin{array}{l}\text { Circumfe } \\
\text { rence (cm) }\end{array}$ & 0,26 & 1 & & & & & \\
\hline Weigh (g) & 0,80 & 0,58 & 1 & & & & \\
\hline Shap & $-0,59$ & 0,04 & $-0,38$ & 1 & & & \\
\hline Tuber skin color & 0,10 & 0,20 & 0,15 & $-0,01$ & 1 & & \\
\hline Rootlets & 0,19 & $-0,09$ & 0,13 & $-0,19$ & $-0,11$ & 1 & \\
\hline Stripes & 0,17 & 0,12 & 0,13 & $-0,12$ & 0,40 & 0,03 & 1 \\
\hline
\end{tabular}

\section{Discussion}

Two (02) months after transplantation, the seedling recovery rate is $55.41 \%$ in agro-ecological zone IV and $23.6 \%$ in agrecological zone V. The recovery rates of Dioscorea cayenensis-Dioscorea rotundata species complex obtained in the same study area is 55.41\% [21]. These recovery rates of Dioscorea cayenensis-Dioscorea rotundata species complex seedlings are lower than the response obtained in Dioscorea alata seedlings in Vanouatou, which is 100\% after transplantation [26]. This difference could be explained by the vigor of the seedlings before transplanting. In the present study, Dioscorea cayenensis-Dioscorea rotundata species complex seedlings were transplanted at a development stage of 12 weeks after sowing while those of Dioscorea alata were transplanted at 24 weeks of development. The high recovery rate (56\%) obtained in the agroecological zone IV result of the environment and climatic conditions of this zone, which are similar with these of the seed-sowing zone. The recovery rate of seedling is acceptable (more than 50\%) when there is not significant difference between climatic and environment conditions of seed sowing zone and seedling transplanted zone. Humidity of the transplanted site is very important for the development of seedlings, because the transplants are very vulnerable of water deficit the first weeks after their transplantation [27] ; transplants are very vulnerable to water deficit in the first weeks after their transplantation [Zoundjihékpon, 2020, pers. comm].

The tuberization rate is similar in the two studies area, $57.63 \%$ in agroecological zone IV and $55.64 \%$ in agroecological zone $\mathrm{V}$. Nevertheless, between seedlings performance, difference is very significant, with respectively $24.9 \pm 19.2 \mathrm{~g}$ for agroecological zone IV and $10.30 \pm 9.91 \mathrm{~g}$ for agroecological zone $\mathrm{V}$.

Seedlings produce from cultivated yam's seeds have received allelic combinations, which allow them to adapt in the both agro-systems, like cultivated yam's $[19,28]$ or wild yams, which disperse by sexual way in their natural ecosystems, are adapted in this hostile environment $[29,30]$.

In the agroecological zone $\mathrm{V}, 43.65 \%$ of the first generation tubers are branched and various shape are been observed in the both agroecological zones. These various shapes of the first generation tubers had been mentioned by more authors in the pass $[11,20,21,26]$. The ramifications or digitations and roots observed on the first generation tubers are wild characters which will disappear over time, as during domestication of wilds ancestors [31] to have better agronomic and morphological performance. Concerning rootlet, $88,89 \%$ of Dodo A tuber of agroecological zone $\mathrm{V}$ have rootlets, but in the agroecological zone IV $85,92 \%$ of tubers of this accession are without rootlets. This result show that this character expression is under environment and climatic conditions.

These wild characters are the expression of some genes, which were repressed in the cultivated germplasm by domestication process. These types of natural hybridizations between cultivated and wild clones have been observed in the other species such as cassava germplasm [32]. These types of hybrids between cultivated and wild yams found in forests and savannas are considered wild, for that, some authors have argued that not all wild yams are wild [33]. The stability of the pollen grains size between Dioscorea cayenensis-D. rotundata complex species [34], could promote gene flow between cultivated and wild yam. 
Sexual reproduction served to develop new varieties of cassava (Manihot esculenta) [17] and in yams (Dioscorea alata) in the West Indies [26, 35]. It offers possibilities for obtaining new high-yielding varieties adapted to current climatic conditions, as new varieties adapted to different agroecological zones and tolerating peasant cropping constraints [33]. Without that, the agro-biodiversity food, humanity food reservoir [36] which contributes of rural population's income and socio life [37] is threatened.

\section{Conclusion}

This study show that the yam's seeds produced by sexual reproduction can be used of yams production. The seeds offer a great varietal genetic diversity of yams. The strong heterogeneity of tubers obtained by this method shows that seeds can be used to create varietal diversity. It's a strength way to improve cultivated yam's germplasm, and supply the genetic erosion caused by unsuitable climatic conditions and the impoverishment of the soil. Seedlings can outlive in various climatic conditions. However, it is preferable to sow the seeds directly in the transplantation areas to avoid the influence of climatic variations between the germination site and the seedling-transplanted site.

\section{Compliance with ethical standards}

\section{Acknowledgments}

We are grateful to our yam's farmer. A big thanks to Nicolas KPATOUKPA and Omer AGOLIGAN who for their assistance for the experimental stage.

Disclosure of conflict of interest

All authors declare no conflict of interest.

\section{References}

[1] Olympio HK. Yam in Togo. In Yams-Ignames. Oxford Sci. Edited by Miège \& Lyonga S. N. 1982; $173-184$.

[2] Osagie AU. The yam tuber in storage. Post-harvest Research Unit. Benin City, Nigeria. $1992 ; 247$.

[3] Heller NE, Zavaleta ES. Biodiversity management in the face of climate change: a review of 22 years of recommendations, Biological Conservation. 2009; 142: 14-32.

[4] Zakari DM, Mohammed AB, Medugu NI, Sandra I. Impact of climate change on yam production in Abuja, Nigeria, International Journal of Science, Environment I and Technology. 2014; 3(2): 458-472.

[5] FAO. Food and Agriculture Organization. FAOSTAT Database. 2010.

[6] Ndjendolé S, Malibangar A. Integration of the National Action Program for Adaptation (NAPA) to Climate Change in the Poverty Reduction Strategy Paper (PRSP 2008-2010). 2009.

[7] Harrison M, Boulahya M. Analysis of Climate Risks in the Central African Republic, in Environmental Management for Sustainable Growth. Flight. 2010; II 1: 166.

[8] Trouslot MF. Growth analysis and morphogenesis of D. cayenensis-D. rotundata yam. State doctoral thesis, University of Clermont-Ferrand II, France. 1983; 247.

[9] Akoroda MO. Estimating pollen viability for controlled hybridization in white yam, Crops Res. (Hort. Res.). 1984; 24: 11-22.

[10] Abraham K. Dormancy and viability of Dioscorea alata seeds, Journal of Root Crops. 1992; 18(2): 142-143.

[11] Zoundjihékpon J. Reproductive biology and genetics of cultivated West African yams, Dioscorea cayenensisrotundata, Doctoral thesis from the National University of Côte d'Ivoire, Genetics and Plant Breeding Specialty. $1993 ; 306$.

[12] Yolou M, Zoundjihekpon J, Tiama D, Anizehou SI, Assaba EI, Adechokan HAAM, Zongo JD, Akoegninou A. Evaluation of yam (Dioscorea cayenensis-Dioscorea rotundata) seed germination grown in Centre Benin, International Journal of Advanced Research. 2015; 3(12): 27 -284.

[13] Quenum A. Morphological characterization of yam of Dioscorea cayenensis-Dioscorea rotundata species complex seed from three communes in Benin and evaluation of their germination. Master's thesis in Genetics, 
Botechnologies and Biological Resources, Plant Genetic Resources and Plant Improvement Option, University of 'Abomey Calavi. 2017; 97.

[14] Dumont R. Etude morphobotanique des ignames Dioscorea cayenensis- D. rotundata cultivées au Nord -Bénin. L'agronomie Trop. 1977; 32: 225-241.

[15] Stessens J. Technical and economic analysis of agricultural production systems in the north of the Ivory Coast. Katholieke Universiteit Leuven. 2002; 302.

[16] M Yolou, I Anizèhou, R Dossou-yovo, A Akoègninnou, J Zongo, J Zoundjihékpon. Etat des lieux de la reproduction sexuée des ignames africaines Dioscorea cayenensis - Dioscorea rotundata cultivées au Bénin, Int. J. Biol. Chem. Sci. 2015; 9(2): 737-750.

[17] Elias M, Penet L, Vindry P, McKey D, Panaud O, Robert T. Unmanaged sexual reproduction and the dynamics of genetic diversity of a vegetatively propagated crop plant, cassava (Manihot esculenta Crantz), in a traditional farming system, Mol. Ecol. 2001;10: 1895-1907.

[18] Tostain S, Chaïr H, Scarcelli N. Diversity, origin and evolutionary dynamics of cultivated yams Dioscorea rotundata Poir. in Benin.', in The acts of the BRG. (ed.) BRG national conference on a dialogue for genetic diversity. Lyon. 2005; 465-82.

[19] Dumont R, Zoundjihékpon J, Vernier P. Origin and diversity of yams Dioscorea rotundata Poir. How the knowhow of African farmers enables them to use wild biodiversity in agriculture, Cahiers d'Agriculture. 2010; 19(4): 255-261.

[20] Abraham K, Nair SG, Sreekumari MT, Unnikrishnan M. Seed set and seedling variation in greater yam (Diosorea alata), Euphytica. 1986; 35: 337-343.

[21] Yolou M. Genetic diversity of cultivated African yams (Complex Dioscorea cayenensis-D. rotundata and D. dumetorum) and perception of the peasants of Center-Benin of questions of intellectual property rights. Doctoral thesis from the University of Abomey-Calavi, Specialty Phytogenetic Resources and Plant Breeding. 2016 ; 155.

[22] IITA. Données climatiques de la Commune d'Abomey Calavi. 2016.

[23] PANA. Benin's National Climate Change Adaptation Program Ministry. 2007; 81.

[24] Assaba EI, Mounirou Y, Totin Vodounon H, Quenum G, Zoundjihèkpon J. Characteristics of cultivated yam seeds of the Dioscorea cayenensis-Dioscorea rotundata species complex and evolution of seed germination rate, Afrique Science. 2018; 14(4): 195 - 208.

[25] IPGRI/IITA, Descripteurs de l'igname (Dioscorea spp.). 1997.

[26] Labeyrie V. Evaluation of an innovative practice: the use and production of seeds of plants with roots and tubers for the distribution and creation of allelic diversity. Montpellier SupAgro, France. 2009; 94.

[27] Ortiz R. Breeding for potato production from true seed, Plant Breeding Abstracts. 1997; 67(10): 1355-1360.

[28] Hamon P, Dumont R, Zoundjihèkpon J, Tio-Touré B, Hamon S. Wild yams from West Africa. Morphophysiological characterizations.CIRAD. 1995; 84.

[29] Zoundjihèkpon J, Hamon P, Noirot M, Tio-Touré B, Hamon S. Flowering synchronisation between male and female West African cultivated yams (Dioscorea cayenensis-rotundata complex), Euphytica. 1997; 95: 371-375.

[30] Scarcelli N. Structure and dynamics of a vegetatively propagated cultivated plant: the case of yams in Benin (Diascorea sp.). Doctoral thesis, University of Montpellier II, France. 2005; 229.

[31] Dansi A. Collecte et caractérisation des ignames cultivées du complexe Dioscorea cayenensis - D. rotundata du Bénin, Thèse de doctorat de l'Université Nationale de Côte d'Ivoire, Spécialité Génétique et Amélioration des Plantes. 2001.

[32] Duputié A, David P, Debain C, McKey D. Natural hybridization between a clonally propagated crop, cassava (Manihot esculenta Crantz) and a wild relative in French Guiana, Mol. Ecol. 2007; 16(14): 3025-3038.

[33] N Scarcelli, H Chaïr, S Causse, R Vesta, TLP Couvreur, Y Vigouroux. Crop wild relative conservation: Wild yams are not that wild, Biol. Conserv. 2017; 201: 325-333.

[34] Assaba EI, Mounirou Y, Denadi N, Anizehou I, Zoundjihèkpon J. Variability of pollen grains in clones of Dioscorea cayenensis-D. rotundata complex grown in Centre of Benin, International Journal of Biosciences. 2020; 16(2): 323 - 331. 
[35] INRA. L'igname dossier documentaire en ligne, INRA, 2006. [Online]. 2006.

[36] Biowacth WR. Privatization of means of survival: the commercialization of biodiversity of Africa. Global trade and biodiversity in conflict, Gaia / GRAIN, ${ }^{\circ}{ }^{\circ} 5.2000$.

[37] Baco M. Domestication of wild yams in the sub-prefecture of Sinendé: local knowledge and endogenous practices for genetic improvement of Dioscorea abyssinica Hochst. Engineering thesis, National University of Benin. 2000; 172. 